\title{
Pendidikan Agama Kristen Bagi Remaja Madya Di Masa Pandemic Covid 19
}

\author{
Rikardo Dayanto Butar-Butar ${ }^{1 *}$, Yudhy Sanjaya ${ }^{2}$, Yoeli Zai ${ }^{3}$, Yuliati Siantajani ${ }^{4}$ \\ ${ }^{1,3}$ Prodi PAK, STT Real Batam \\ ${ }^{2}$ Prodi Teologi, STT Real Batam \\ ${ }^{4}$ Prodi PK-AUD, STT Real Batam \\ rikardobutar@gmail.com
}

\begin{abstract}
During the COVID-19 pandemic, Madya teenagers experienced the challenges of Christian religious education in schools and churches. Social distancing has the potential to take away social interaction with teachers, mentors and peers. Meanwhile, the transitional period of middle adolescence is a period of self-discovery. Christian religious education is being challenged again. During the pandemic, whether parents are ready or not, it is inevitable to accompany teenagers in the distance learning process. The purpose of this study is to ensure that the implementation of Christian religious education remains optimal, especially in the context of a pandemic. This research uses descriptive qualitative method. Parents must double function as caregivers as well as direct companions in the implementation of Christian religious education for teenagers in the midst of neglecting the offline learning process at school.
\end{abstract}

Keywords: Youth, Parents, Covid 19, Education, Christianity.

\begin{abstract}
Abstrak
Di masa pandemi covid 19 remaja Madya mengalami tantangan pendidikan agama Kristen di sekolah dan gereja. Social distancing berpotensi merenggut interaksi social dengan guru, pembimbing dan teman sebaya. Sementara masa transisi remaja madya ini merupakan masa pencarian jati diri. Pendidikan agama Kristen ditantang kembali. Dalam masa pandemi siap atau tidak orang tua tidak terelakkan untuk mendampingi remaja dalam proses pembelajaran jarak jauh. Tujuan penelitian ini adalah agar penyelenggaraan pendidikan agama Kristen tetap optimal terutma dalam konteks pandemi. Penelitian ini menggunakan metode kualitatif deskriptif. Orang tua harus berfungsi ganda sebagai pengasuh sekaligus sebagai pendamping langsung penyelenggaraan pendidikan agama Kristen bagi remaja di tengah kealpaan proses pembelajaran secara luring di sekolah.

Kata kunci: Remaja, Orang tua, Covid 19, Pendidikan, Kristen.
\end{abstract}




\section{PENDAHULUAN}

Setiap Masa remaja merupakan masa yang unik, asyik, beresiko dan menentukan. Unik karena dalam masa remaja ada banyak hal yang sulit dipahami terkait tingkah laku, keputusan, pergaulan dan kehidupan remaja lainnya. Asyik karena dimasa remaja ada banyak momentum istimewa dalam berbagai aspek kehidupan sebagai remaja. Beresiko berkaitan dengan tingginya rasa penasaran dan keingintahuan remaja yang sedang berdiri dipersimpangan jalan dalam menentukan pilihan-pilihan terbaik baginya. Dan menentukan karena di masa peralihan pilihan-pilihan dan keputusan yang dibuat saat remaja sangat mempengaruhi berbagai proses kehidupan selanjutnya. Karena itu porsi pendidikan, perhatian, bimbingan dan pendampingan untuk remaja harus maksimal dalam segala aspek.

Remaja yang hidup era digital dan media sosial memiliki berbagai persoalan sebagai dampak dari berbagai kemajuan tersebut. Berbagai kenakalan remaja yang jamak terjadi di tengah masyarakat seperti tawuran, ketergantungan game online dan media social, penyalahgunaan internet, kecanduan menonton film porno, merokok, narkoba, minuman keras, seks pra nikah menjadi tugas yang mendesak dicegah dan ditangani. Tindakan pencegahan dan penanganan berbagai kenakalan remaja tersebut mendapat tantangan yang semakin rumit akibat pandemi penyebaran virus Covid 19. Pandemi ini telah mengubah banyak tatanan kehidupan masyarakat, terkhusus kehidupan para remaja. Belajar dari rumah dan banyaknya waktu luang para remaja menjadi masalah baru karena menjadi celah dan terbukanya peluang besar bagi para remaja masuk dalam jeratan berbagai kenakalan remaja. Salah satu fakta terkait sebagaimana diwartakan dalam berita KompasTV pada Jumat 24 April 2020, yang memberitakan; "Ada lima orang remaja yang sedang pesta minuman keras terjaring razia penyakit masyarakat, yang digelar oleh Satuan Polisi Pamong Praja Kota Blitar Jawa Timur pada Rabu (22/04)."

Banyaknya waktu luang remaja dan program belajar dari rumah di masa pandemi covid 19 menjadi ruang besar bagi remaja terjerat masuk dalam berbagai kenakalan remaja. Belajar dari rumah memberikan akses dan fasilitas bagi remaja memiliki kesempatan luas dan bebas terhadap penyalahgunaan media social dan jaringan internet. Minimnya pengawasan dari orang tua akibat belajar dari rumah menjadi pekerjaan rumah yang mendesak. Sebelum pandemi para remaja setidaknya berinteraksi sosial dalam lingkungan sekolah dalam pengawasan para guru di sekolah. Di masa seperti pandemi ini, kesempatan itu hilang akibat belajar dari rumah. Waktu tujuh sampai delapan jam setiap hari adalah rentang waktu yang begitu besar 
yang memberikan peluang bagi para remaja masuk dalam jeratan berbagai kenakalan remaja. Sebab mereka memiliki perangkat akses dan fasilitas internet dan media social yang disediakan orang tua untuk mendukung program belajar dari rumah. Dimasa pandemi ini ada banyak remaja yang tidak mendapat pengawasan dan pendampingan belajar dari rumah dengan berbagai alasan. Ada orang tua yang sibuk bekerja, memiliki waktu dirumah namun minim pengetahuan untuk mendampingi dan menyelenggarakan belajar di rumah.

Remaja sebagai masa depan keluarga, gereja dan bangsa di tengah pandemi membutuhkan perhatian, pendidikan dan pendampingan maksimal. Para remaja harus dipersiapkan menjadi pemimpin dimasa depan. Kondisi Pandemi tidak boleh menjadi alasan pembiaran para remaja kehilangan momentum pendidikan berharga yang sangat menentukan masa depan mereka. Remaja Kristen perlu pembekalan pendidikan agama Kristen yang efektif bagi mereka dimasa pandemi covid 19. Orang tua sebagai guru utama dan pertama harus hadir menyelenggarakan Pendidikan Agama Kristen bagi remaja dimasa-masa mereka memiliki banyak waktu luang karena praktek belajar dari rumah. "Beragam permasalahan yang dihadapi oleh para remaja, mulai dari masalah pertemanan, masalah sekolah, masalah pergaulan, masalah penampilan dan lain sebagainya." Mengingat masalah tersebut, para remaja perlu mendapat perhatian serius sehingga persoalan-persoalan remaja dapat diatasi dengan baik dan mencegah timbulnya berbagai aksi kenakalan remaja lainnya.

\section{METODE}

Artikel ini dibuat dalam bingkai penelitian kualitatif deskriptif, dimana data berasal dari data sekunder dari berbagai literature dan observasi. Penelitian didasarkan atas fenomena sosial kehidupan remaja madya yang rata-rata duduk dibangku Sekolah Menengah Atas di tengah Pandemi Covid 19. Metode Kualitatif adalah sebuah penelitian ilmiah yang di dalamnya membahas fenomena dimana bertujuan untuk memahami fenomena tersebut dalam proses interaksi komunikasi yang inten antara peneliti dengan fenomena yang diteliti. ${ }^{2}$

${ }^{1}$ Ester Lina, Situmorang Rikardo, and Mega Mustika Zega, "Kriteria Guru Pak Dalam Membentuk Jati Diri Remaja Usia 12 - 15 Tahun,” Didache 4, no. 2 (2019): 25-33. Hal, 26

${ }^{2}$ Sugiyono, "Memahami Penelitian Kualitatif," Bandung: Alfabeta (2016)., hal. 14 


\section{HASIL DAN PEMBAHASAN}

\section{Pendidikan Agama Kristen Bagi Remaja Madya Dimasa Pandemic Covid 19}

Fenomena belajar dari rumah akibat pandemi Covid 19 mengharuskan setiap orang beradaptasi dengan kebiasaan baru. Pendidikan Agama Kristen di Gereja dan Sekolah tidak dapat diselenggarakan lagi seperti metode pada umumunya sebelum pandemi. Remaja madya yang sedang berdiri dipersimpangan dan masa transisi sangat rentan dan mudah terpengaruh oleh berbagai hal negative yang bisa membawa mereka masuk dalam berbagai kenalan remaja.

Pendidikan agama Kristen sebagai jalan mempertemukan remaja dengan Kasih Allah sangat dibutuhkan untuk membentuk remaja madya sehingga mengalami perkembangan pikiran, perasaan dan kehendak yang selaras dengan pikiran, perasaan dan kehendak Kristus. Dengan demikian remaja madya memiliki karakter Kristus dengan kemandirian sikap dan tingkah laku supaya siap berbaur dalam masyarakat, yang mencerminkan Kristus yang bisa hidup dan menerima setiap orang dengan berbagai latar belakang kehidupan. Hal ini pernah penulis tegaskan dalam tulisan sebelumnya bahwa Menerima, mengasihi setiap orang sebagai sesama merupakan pokok pengajaran Tuhan Yesus yang wajib dihidupi oleh setiap orang percaya. ${ }^{3}$

Di masa Pandemi Covid 19, remaja madya menghadapi tantangan dan godaan besar yang bisa menjerat mereka masuk dalam keputusan dan perilaku yang merugikan diri sendiri, keluarga, gereja dan juga masyarakat. Karena itu Pendidikan Agama Kristen wajib dihadirkan untuk menjawab kebutuhan para remaja madya. Karena itu Pendidikan Agama Kristen di masa pandemi covid 19, diwujudkan dengan konsep yang aktual bagi para remaja madya.

\section{Orang Tua Sebagai Guru Utama dan Pertama.}

Konsep orang tua sebagai guru utama dan pertama bukanlah ide atau konsep yang baru. Namun demikian, pemikiran bahwa orang tua sebagai guru utama dan pertama sangat relevan terutama di tengah situasi pandemi covid 19. Orang tua sebagai guru utama dan pertama merupakan amanat firman Allah. Dan terjadinya banyak penyimpangan tingkah laku dan aneka kenakalan remaja disebabkan hilangnya peran orang tua sebagai guru

${ }^{3}$ Rikardo Dayanto Butar-butar et al., "Pengajaran Tuhan Yesus Mengenai Toleransi Dan Implementasinya Ditengah Masyarakat Majemuk" 4, no. 1 (2019): 88-101. Hal, 94 
utama dan pertama. Amanat firman Tuhan untuk melaksanakan Pendidikan Agama Kristen diamanatkan oleh Tuhan kepada orang tua. Dalam Ulangan 6:7 perintah untuk menyelenggarakan pendidikan kepada anak merupakan tangungjawab orang tua. Orang tua harus menjadi pemeran dan penggerak dan penanggungjawab utama dan pertama dalam terlaksananya pendidikan bagi anak remaja.

Sebagai guru utama dan pertama bukan berarti orang tua adalah pribadi yang sempurna. Dalam pandangan Loyola, Luther, Calvin dan banyak tokoh lainnya mengatakan pengajar utama itu adalah Tuhan Yesus sendiri sebab Roh Kristuslah yang memenuhi dan mengubah hati para remaja, dan orang tua tidak mungkin menjadi Yesus Kecil. ${ }^{4}$ Pemahaman iman bahwa Roh Kristus yang memberikan pengertian dan mengubah hati itu dapat diterima, namun dalam fungsi melaksanakan tugas pendidikan dan menuntun para remaja mengenal Kristus adalah tanggung jawab utama orang tua. Dalam hal tersebutlah orang tua berperan sebagai guru utama dan pertama. Selain karakter orang tua juga berpengaruh meneruskan warisan iman, sebagai mana Dwidjo Saputro menuliskan kehangatan orang tua adalah kunci keberhasilan pewarisan iman Kristen. ${ }^{5}$

Di tengah situasi pandemi covid 19, peran dan tanggungjawab orang tua sebagai guru utama dan utama dikembalikan kepada posisi yang seharusnya. Anak remaja madya di masa pandemi covid 19, diwajibkan belajar dari rumah, itu berarti bahwa sepanjang hari para remaja berada dirumah. Sebagai guru utama dan pertama keberhasilan belajar remaja merupakan keberhasilan orang tua sebagai guru utama dan Yesus sebagai guru agungnya. Membangun dan mengembangkan nilai moral dan spritualitas remaja madya di masa pandemi covid 19 ini merupakan tanngungjawab rohani orang tua sebagai guru utama dan pertama. Baik dalam Perjanjian Lama maupun Perjanjian baru Allah memerintahkan orang tua untuk menjadi guru utama. Efesus 6: 4, mengatakan supaya orang tua dalam hal ini bapa-bapa supaya mendidik dalam nasehat dan ajaran Tuhan. Dengan demikian tua orangtua harus berperan menjadi guru yang mengajar dan mengajak para remaja mmengenal dan mengalami kasih Allah. Orangtua mempunyai tanggung jawab dalam mengajarkan firman Tuhan dan peran mereka adalah sebagai pendidik. Sebagaimana dilakukan oleh Lois yang menjadi guru bagi Eunike, dan Eunike menjadi guru bagi Timotius

\footnotetext{
${ }^{4}$ Boehlke, Sejarah Perkembangan Pikiran Dan Praktek Pendidikan Agama Kristen Dari Plato Sampai Ig. Loyola. Hal, 476

${ }^{5}$ Dwidjo Saputro, "Injil Dalam Ruang Kekuatan Keluarga Dan Pernikahan," Webinar Great Commission As Family Lasting Legacy, STT REAL BATAM.
} 
(2Tim 1:5). Sehingga Timotius tumbuh menjadi pribadi yang memiliki pribadi dan karakter Kristus. Kerangka pemikiran atau pandangan dunia tentang pendidikan karakter menurut Yesus didasarkan pada perubahan batin dalam diri seseorang. ${ }^{6}$ Karena itu orang tua sebagai guru utama dan pertama bukanlah pilihan, melainkan amanat Alkitab. Pola hubungan merupakan inti dari seluruh pelayanan dan kehadiran Yesus selama melakukan seluruh pekerjaan-Nya di Bumi. ${ }^{7}$ Karena itu orang tua sebagai guru utama dan pertama bukanlah pilihan, melainkan amanat Alkitab. Peran ini tidak boleh ditunda, terutama disituasi pandemi hari ini, tugas ini harus segera direalisasikan. "Orangtua diharuskan untuk mengajar dan aktif dalam pengajaran mengenai firman Tuhan. Alkitab memerintahkan orangtua mengajarkan kehendak Tuhan kepada anaknya."

Kristus sebagai guru agung memberikan mandat kepada orang tua sebagai perwakilanNya untuk menyampaikan pikiran, perasaan dan kehendak Kristus kepada para remaja madya. Remaja madya dalam perjuangan batin di tengah masa transisinya membutuhkan guru yang membimbing dan mengarahkan mereka untuk mengenal dan berjumpa dengan Kristus. Dan tugas tersebut merupakan tanggungjawab orang tua Kristen sebagai guru utama dan pertama. Sebab itu setiap orangtua Kristen harus terlebih dahulu belajar supaya dapat menjadi pendidik rohani yang baik bagi anak-anaknya. ${ }^{9}$

\section{Yesus Sebagai Pusat Pendidikan Agama Kristen}

Remaja madya di masa pandemi covid 19 diperhadapkan dengan berbagai tantangan kehidupan sebagai remaja. Dunia internet, game online, media social adalah hal-hal yang sangat dekat dan melekat dengan remaja madya. Remaja di tengah situsi tersebut perlu dipersiapkan dengan semaksimal mungkin. Mempersiapkan remaja madya menghadapi segala realitas hidup maka mereka perlu dibekali dengan berbagai pengetahuan dan perjumpaan pribadi bersama dengan Tuhan. "Karena itu pendidikan agama Kristen disajikan dengan pengajaran yang berpusat langsung dengan Tuhan

\footnotetext{
${ }^{6}$ Noh Ibrahim Boiliu et al., "Mengajarkan Pendidikan Karakter Melalui Matius 5:6-12," Kurios (Jurnal Teologi \& Pendidikan Agama Kristen) 6, no. 1 (2020): 61-72.

${ }^{7}$ Fredy Simanjuntak, "Problematika Disorganisasi Dan Disharmonisasi Keluarga," in Keluarga Yang Misioner, 2018, 81-91.

${ }^{8}$ Christa Siahaan and \& Anneke Rantung, "Peran Orang Tua Sebagai Pendidik Dan Pembentuk Karakter Spiritualitas Remaja," Pendidikan Agama Kristen SHANAN (2019). Hal, 99

${ }^{9}$ Ibid.
} 
Yesus Kristus. Sebagai guru agung pendidikan agama Kristen harus berpusat kepada Kristus juga membawa orang kepada Kristus." 10

Remaja madya adalah masa dimana mereka mulai mengagumi tokoh-tokoh yang mereka anggap hebat, heroik dan biasanya dijadikan sebagai inspirasi. Saat ini ada banyak diciptakan figur-figur berupa super hero yang diproduksi dan dikampanyekan lewat berbagai media, dalam bentuk film, video, iklan dan lain sebagainya yang mudah diakses oleh para remaja. Pengaruh tokoh fiksi dalam wujud super hero tersebut sangat diminati remaja madya, karena itulah Pendidikan agama Kristen disajikan dengan menampilkan Yesus sebagai pusat pendidikan Kristen. Sebagaimana yang dinyatakan dalam Ibrani 5:7-9 yang memberikan penegasan bahwa Tuhan Yesus Kristus adalah pribadi yang sempurna dan hidupNya dapat dijadikan teladan bagi setiap orang yang percaya pada Nya. Pendidikan agama Kristen akan kehilangan makna dan tujuannya ketika Tuhan Yesus bukan lagi menjadi pusat dan tujuan pendidikan Kristen. Remaja madya perlu dipersiapkan supaya memiliki pikiran dan karakter Kristus. Mewujudkan tujuan tersebut maka di masa pandemi covid 19, Kristus harus menjadi tokoh sentral, pemberitaan utama, pusat dan arah pendidikan Kristen itu sendiri. Sebab keselamatan, pengampunan dosa adalah karya dan karunia Tuhan Yesus Kristus bagi semua orang, demikian juga halnya dengan dan masa depan.

\section{Teladan Hidup Sebagai Nyawa Pendidikan Agama Kristen}

Perkembangan kognisi remaja madya ada dalam tahap perkembangan menuju kedewasaan, difase ini hal-hal yang bertentangan dengan apa yang mereka pikirkan akan mereka protes. Mereka tidak menerima sesuatu begitu saja. Karena itu lingkungan sekitarnya, apa yang dilihat, didengar dan dialaminya menjadi referensi dalam bersikap dan berperilaku. Sebagaimana yang dinyatakan oleh Sherian Sekar bahwa Kepribadian remaja sangat ditentukan oleh faktor lingkungan sekitarnya, apakah mendukung dia menjadi pribadi yang lebih baik atau bahkan sebaliknya. Salah satu -faktor yang dapat mempengaruhi perkembangan emosi remaja adalah perubahan pola interaksi dengan orangtua. ${ }^{11}$ Sebab itu orang tua sebagai penyelenggara utama Pendidikan Agama Kristen harus menjadikan teladan sebagai sarana atau nyawa dari pendidikan agama

\footnotetext{
${ }^{10}$ Boehlke, Sejarah Perkembangan Pikiran Dan Praktek Pendidikan Agama Kristen Dari Plato Sampai Ig. Loyola. Hal, 57

${ }^{11}$ Sherien Sekar, Dwi Ananda, and Nurliana Cipta Apsari, "MENGATASI STRESS PADA REMAJA SAAT PANDEMI COVID-19" (2020). Hal, 250
} 
Kristen. Sangat tidak mungkin menyampaikan kebenaran, nilai moral, integritas, dan keseluruhan kehidupan Tuhan Yesus Kristus tanpa teladan hidup.

Teladan hidup Yesus, karakterNya, pemikiranNya, pengorbananNya dan semua karyaNya mustahil dan sulit diajarkan dengan kata dan teori. Teladan hidup akan sangat hidup dan kuat membekas bagi kehidupan remaja madya. Media social, internet yang dekat dan lekat dengan lingkungan remaja madya menawarkan dan mengajarkan aneka praktek kehidupan, baik maupun buruk. Semuanya itu akan mempengaruhi dan membentuk kehidupan remaja madya. Karena itulah pedidikan Agama Kristen wajib bernyawa dan bernafaskan teladan. Yang dimulai dari penyelenggara dan penanggungjawab utama pendidikan Agama Kristen, yaitu orang tua. Sebagaimana juga Yesus praktekkan dalam hidup dan pelayanannya.

Teladan hidup jauh lebih tajam dari perkataan. Kisah Tuhan Yesus membasuh kaki murid-muridNya merupakan salah satu pembalajaran yang sangat efektif untuk menamkan nilai tentang merendahkan diri serta melayani kepada para murid-muridNya. Karena itulah dengan tegas dan lugas Yesus menyampaikan tentang pentinya teladan bagi para murid. Dengan berkata bahwa jika kamu menyebut Aku sebagai Guru dan Tuhan, maka kamu wajib mengikuti apa yang sudah kulakukan kepadamu, wajib engkau praktekkan dengan sesamamu. (Yohanes 13:13-14). Kekuatan teladan sebagai nyawa pendidikan Agama Kristen juga disampaikan oleh Rasul Paulus, yang megajak utuk mengikuti teladannya, sama seperrti dia juga mengikuti teladan Kristus. (I Korintus 11:1). Yang kemudian dilanjutkan dengan berkata bahwa orang percaya adalah surat pujian yang tertulis yang dapat dibaca oleh semua orang. (II Korintus 3:2).

Nilai moral, integritas, karya Kristus sulit dijelaskan hanya melalui kata-kata saja, teladan adalah sarana efektif menyampaikan kebenaran Alkitabiah. Yesus sebagai poros pendidikan Kristen sudah mewariskan teladan sempurna kepada para murid. Para Murid, para rasul, pahlawan iman dan tokoh-tokoh gereja sudah mengerjakannya. Remaja madya yang sedang mencari jati dirinya akan lebih mudah dibawa mengenal kasih Allah dan bersaksi tentang Kristus melalui praktek hidup atau teladan. Terlebih di tengah situasi pandemi covid 19, meraka butuh teladan, panutan sebagai representasi Kritus dalam pendidikan Agama Kristen, sekaligus membawa mereka keluar dari berbagai pengaruh negative dari lingkugan mereka sebagai remaja. 


\section{Orang Tua Sebagai Sahabat Remaja Madya}

Salah satu konsekunsi dari belajar dari rumah bagi remaja madya adalah minimnya interaksi dengan komunitas teman sebaya. Belajar dari rumah membatasi interaksi social dengan teman sebaya yang selama ini terjadi disekolah atau gereja. Persahabatan dan interaksi social adalah kebutuhan mendasar yang diperlukan untuk perkembangan mental dan spiritual remaja madya. Di tengah situasi pandemi covid 19, orang tua harus hadir dan mengambil peran tersebut. Ini tidak mudah, tetapi bukan berarti tidak bisa. Anak remaja madya butuh interaksi, butuh didengarkan dan orang tua bisa hadir memenuhi kebutuhan tersebut dengan menjadi sahabat bagi remaja. Pendidikan agama Kristen diwujudkan dengan menyampaikan kebenaran Kristus kepada remaja madya melalui persahabatan orang tua dengan remaja madya.

Kerendahan hati dan kerelaan orang tua menghadirkan pendidikan agama Kristen dengan mewujudkan persahabatan akan memudahkan adaptasinya dengan remaja madya. Amsal 17:17, memberikan tuntunan bagaimana menjadi sahabat bagi remaja madya, yaitu menaruh kasih setiap waktu, dan menjadi sahabat dalam kesukaran. Kebenaran ini menjadi penuntun Pendidikan Agama Kristen bagi remaja madya dimana kehadiran orang tua sebagai sahabat dapat mengisi kealpaan sahabat remaja madya. Sebagai sahabat, orang tua belajar terbuka kepada remaja madya sehingga mereka juga akan terbuka dan menyampaikan baik pikiran, ide dan juga perasaan-perasaannya kepada orang tua yang telah menjadi sahabatnya. Sebagai saudara orang tua memposisikan diri dengan menunjukkan sikap empati ketika remaja madya menghadapi berbagai kesulitan-kesulitan yang dihadapi remaja madya.

Menjadi sahabat bagi remaja madya berarti orangg tua harus banyak belajar dan memahami karakteristik remaja modern, dimana keadaanya jauh berbeda dengan pengalaman masa remaja orang tua terdahulu. Mewujudkan pendidikan agama Kristen remaja dengan persahabatan, akan memberikan keuntungan dan kemudahan besar bagi orang tua. Dengannya orang tua segera mengetahui kondisi dan pengalaman remaja madya. Persahabatan dengan remaja madya dapat dibangun oleh orang tua dengan belajar menjadi pendengar yang baik bagi remaja, tidak mendominasi percakapan, menghargai setiap pikiran dan keputusan remaja madya. Menghormati mereka sebagai sahabat dengan menempatkan bahwa mereka adalah setara. 


\section{Rumah Sebagai Ruang Kelas Yang Kondusif.}

Belajar dan pembelajaran dapat dilakukan dimana saja. Ulangan 6:7-9, orang tua dalam menyelenggarakan pendidikan kepada anak tidak dibatasi oleh ruang dan tempat. Dimana saja boleh belajar. Dirumah, diperjalanan, atau tempat lainnya bisa menjadi tempat yang kondusif untuk menyampaikan kebenaran kepada remaja. Namun dalam situasi pandemi covid 19 saat ini rumah adalah tempat paling aman dan nyaman untuk menyelenggarakan pendidikan. Rumah perlu diwujudkan sebagai ruang belajar, ruang kelas, ruang interaksi belajar remaja. Dari laporan hasil survey KPAI, menyatakan bahwa; Salah satu faktor penyebab tingkat stress anak remaja adalah mengalami kesulitan saat harus belajar di rumah akibat pandemi. Dari survey KPAI, 79,9 \% anak berpendapat bahwa interaksi berkurang dan guru hanya memberikan tugas saja sehingga anak mengalami peningkatan stress dan 20,1\% menganggap adanya interaksi dalam proses pembelajaran. ${ }^{12}$ Hal semacam ini bisa diatasi ketika orang tua bisa menciptakan rumah sebagai ruang kelas yang kondusif untuk belajar.

Rumah sebagai ruang kelas yang kondusif bukan saja berkaitan dengan fasilitas yang ada, namun pada penekanan kualitas interaksi yang terjadi antar individu dalam keluarga. Pendidikan agama Kristen bagi remaja akan sangat efektif ketika remaja madya tumbuh di tengah keluarga yang menjadikan rumah sebagai tempat belajar dan tumbuh bersama. Rumah menjadi tempat menumbuhkan dan mencurahkan cinta kasih antar individu yang hidup bersama dibawah satu atap, yaitu rumah. Kemampuan orang tua menjadikan rumah sebagai ruang kelas yang kondusif dimana antar individu hidup bersama dalam cinta kasih, persahabatan, saling menerima kelebihan dan kekurangan, saling peduli, gotong-royong dan kerja sama, adalah perwujudan pendidikan agama Kristen yang sebenarnya. Dan model pendidikan yang demikianlah yang paling efektif membentuk kepribadian remaja madya menjadi pribadi yang bisa melihat tanda dan kehadiran Kristus di tengah keluarga.

\section{Bimbingan dan Dialog Sebagai Metode Pendidikan Agama Kristen}

Remaja madya yang sedang berada dalam pencarian jati diri menghadapi berbagai konflik batin yang membutuhkan penyelesaian mendesak. Andar Ismail menyatakan kehadiran Pendidikan agama Kristen diperlukan sebagai jawaban untuk menyelamatkan para remaja dari

12 Ibid. hal 250 
ketimpangan dunia pendidikan masa kini. ${ }^{13}$ Sedangkan Paulus Lilik Kristanto berpendapat untuk membangun filosofi yang Alkitabiah dan konstruktif untuk melayani, dan juga untuk Membuka diri untuk gaya hidup mereka dengan mendorong sisi-sisi positif yang mereka miliki. ${ }^{14}$ Mewujudkan tujuan tersebut pendidikan agama Kristen perlu didesain dan diselenggarakan dengan sedemikian rupa sehingga mampu menjawab kebutuhan remaja madya yang lekat dan dekat dengan kemajuan teknologi informasi di masa pandemi dovid 19 ini. Karena itu pendidikan agama Kristen perlu dihadirkan dengan metode dan pendekatan sederhana yang adaftif dengan kehidupan remaja madya masa kini melalu metode bimbingan dan dialog.

Metode bimbingan adalah salah satu metode mengajar Tuhan Yesus ketika mengajar para murid. Setelah ceramah Yesus memberikan bimbingan kepada para murid melalui tinjuann yang harus diamalkan. Misalnya dalam Matius 10, para murid diberikan petunjuk oleh Yesus untuk mengusir roh jahat, melenyapkan penyakit dan kelemahan serta memberitakan kerajaan sorga sudah dekat (Matius 10:7). ${ }^{15}$ Berikutnya Yesus menentukan apa yang harus mereka kerjakan, kemana para murid harus pergi (Matius 10:5-6). Bimbingan Yesus kepada para murid ini begitu efektif menjadikan mereka terdidik dalam pelayanan dan siap terjun dalam pelayanan. Bagi remaja madya yang tertarik ketika diberikan kesempatan, maka metode ini sangat tepat bagi mereka. Pendidikan agama Kristen memiliki banyak petunjuk yang perlu diparaktekkan langsung oleh para remaja, maka metode bimbingan ini sangat baik. Dalam hal ini orang tua menempatkan posisi sebagai mentor atau pembimbing bagi remaja. Orang tua menyampaikan nilai-nilai kebenaran Kristus dengan jelas dan memantau remaja madya mempraktekkan nilai-nilai tersebut.

Berikutnya metode pendidikan agama Kristen yang efektif untuk remaja madya di masa pandemi covid 19 adalah dialog. Dialog adalah salah satu metode yang banyak dipraktekkan oleh Tuhan Yesus Kristus dalam perjalanan pelayananNya. Keempat injil mencatat ada banyak contoh metode dialog yang Yesus praktekkan. Salah satu praktek metode dialog yang sangat efektif dalam pengajaran Tuhan Yesus adalah kisah dalam Yohanes pasal empat, yaitu percakapan dengan perempuan Samaria. Efektifitas metode tersebut begitu jelas dari titik balik dan pertobatan perempuan Samaria Hal, 140

${ }^{13}$ Andar Ismail, Ajar Mereka Melakukan (Jakarta: PT. BPK Gunung Mulia, 2012).

\footnotetext{
${ }^{14}$ Paulus Lilik Kristianto, Prinsip Dan Praktik PAK (Yogyakarta: Andi, 2006). Hal, 96

${ }^{15}$ Boehlke, Sejarah Perkembangan Pikiran Dan Praktek Pendidikan Agama Kristen Dari Plato Sampai Ig. Loyola. Hal 66
} 
tersebut. Sebagaimana dikatakan; Dialog berperan penting dalam pelayanan Tuhan Yesus ketika mengajar perempuan Samaria. Yesus memulia dialognya dengan "Berilah Aku Minum" melalui keperluan jasmani yang pokok tersebut membawa perempuan tersebut meninjau ulang kehidupannya yang pada akhirnya sampai kepada pengakuan iman dan memberanikannya bersaksi kepada satu kotanya. ${ }^{16}$

Perempuan Samaria penuh misteri dan gejolak dalam jiwa pada akhirnya terbuka dan menerima pebelajaran melalui metode dialog. Remaja madya dengan segala keberadaanya akan tertolong dan terbuka menerima Kristus, mengamalkan kasih Kristus kepada banyak orang dengan metode tersebut. Metode dialog akan membuka ruang dan pengakuan kepada remaja madya bahwa suara mereka didengar, pendapat mereka dihargai, pikiran dan ide mereka diterima. Alasan itu juga yang menjadikan metode dialog menjadi metode yang sesuai bagi remaja madya masa kini di tengah kondisi pandemi covid 19.

\section{KESIMPULAN}

Remaja madya adalah asset berharga keluarga, gereja dan bangsa. Karena itu harus dipersiapkan, dibekali dengan kebenaran firman Tuhan, mengalami kasih Kristus sehingga mereka tumbuh memiliki karakter, pikiran, perasaan dan kehendak Kristus. Mereka adalah harapan yang akan dipakai menyuarakan kebenaran Kristus di tengah dunia ini. Karena itu tidak boleh ada satu situasi apapun yang menghalangi mereka dipersiapkan dan dibekali dengan pendidikan agama Kristen yang memadai dan maksimal, terutama di tengah hilangnya berbagai kesempatan mereka belajar dan berinteraksi social akibat pandemi covid 19. Remaja madya dengan segala karakeristiknya harus mengenal Kritus dan kasih Allah serta tumbuh dalam karakter dan kehendak Kristus.

Orang tua sebagai penerima mandate Allah harus berperan maksimal dalan tangung jawab menyelenggarakan pendidikan agama Kristen bagi remaja madya. Remaja madya yang dekat dan lekat dengan kemajuan teknologi imformasi, media social dan berbagai kemajuan lainnya harus mendapatkan porsi pendidikan Agama Kristen yang memadai dan maksimal sesuai amanat agung Tuhan Yesus Kristus (Matius 28:20) dan juga perintah Allah dalam Ulangan pasal 6. Sebab itu orang tua harus kembali kepada pangilaanya sebagai guru utama dan pertama. Sebagaimana telah dipraktekkan oleh para rasul, tokoh-tokoh iman sehingga melahirkan

${ }^{16}$ Ibid. Hal, 68 
generasi seperti Timotius. Orang tua sebagai guru utama harus mendasarkan pendidikan agama Kristen berpusat kepada Tuhan Yesus Kristus sebagai pahlawan iman yang menyelamatkan dan menyediakan masa depan. Menjadi sahabat bagi remaja madya juga adalah usaha terapan yang harus diwujudkan, membangun dan memastikan rumah dan keluarga sebagai ruang kelas yang kondusif bagi remaja madya. Dan pendidikan agama Kristen diselenggarakan dengan metode yang bisa dekat dengan karakter remaja madya, yang mengahargai mereka, memberikan ruang dan tempat dimana remaja madya diterima, dihormati dan dihargai, yaitu dengan metode bimbingan dan dialog.

\section{KEPUSTAKAAN}

Boehlke, Robert R. Sejarah Perkembangan Pikiran Dan Praktek Pendidikan Agama Kristen Dari Plato Sampai Ig. Loyola. Jakarta: PT. BPK Gunung Mulia, 2005.

Butar-butar, Rikardo Dayanto, Ester Lina Situmorang, Jabes Pasaribu, and Manahan Uji. "Pengajaran Tuhan Yesus Mengenai Toleransi Dan Implementasinya Ditengah Masyarakat Majemuk" 4, no. 1 (2019): 88-101.

Homrighausen. Pendidikan Agama Kristen. Jakarta: PT. BPK Gunung Mulia, 1996.

Hurlock, Elisabeth B. Psikologi Perkembangan. 5th ed. Jakarta: Erlangga, 2018.

Ismail, Andar. Ajar Mereka Melakukan. Jakarta: PT. BPK Gunung Mulia, 2012.

Jahya, Yudrik. Psikologi Perkembangan,. Jakarta: Kencana, 2011.

Kristianto, Paulus Lilik. Prinsip Dan Praktik PAK. Yogyakarta: Andi, 2006.

Lina, Ester, Situmorang Rikardo, and Mega Mustika Zega. "Kriteria Guru Pak Dalam Membentuk Jati Diri Remaja Usia 12 - 15 Tahun." Didache 4, no. 2 (2019): 25-33.

Noh Ibrahim Boiliu, Aeron Frior Sihombing, Christina M. Samosir, and Fredy Simanjuntak. "Mengajarkan Pendidikan Karakter Melalui Matius 5:6-12." Kurios (Jurnal Teologi \& Pendidikan Agama Kristen) 6, no. 1 (2020): 61-72.

Nuhamara, Daniel. Pendidikan Kristen Remaja. Jawa Barat: Jurnal Info Media, 2008. 
Santrock, Jhon W. AdolescencePerkembangan Remaja. Jakarta: Erlangga, 2002.

Saputro, Dwidjo. "Injil Dalam Ruang Kekuatan Keluarga Dan Pernikahan." Webinar Great Commission As Family Lasting Legacy, STT REAL BATAM.

Sarlito W, Sarwono. Psikologi Remaja. Jakarta: PT Raja Grafindo Persada, 2004.

Sekar, Sherien, Dwi Ananda, and Nurliana Cipta Apsari. "MENGATASI STRESS PADA REMAJA SAAT PANDEMI COVID-19" (2020).

Siahaan, Christa, and \& Anneke Rantung. "Peran Orang Tua Sebagai Pendidik Dan Pembentuk Karakter Spiritualitas Remaja." Pendidikan Agama Kristen SHANAN (2019).

Simanjuntak, Fredy. "Problematika Disorganisasi Dan Disharmonisasi Keluarga." In Keluarga Yang Misioner, 81-91, 2018.

Simanjuntak, Fredy, Dewi Lidya Sidabutar, and Yudhy Sanjaya. "Penggembalaan Dalam Ruang Virtual." Thronos 1, no. 2 (2020): 99-114.

Sugiyono. "Memahami Penelitian Kualitatif." Bandung: Alfabeta (2016).

Susilo, Adityo, Cleopas Martin Rumende, Ceva Wicaksono Pitoyo, Widayat Djoko Santoso, Mira Yulianti, Herikurniawan Herikurniawan, Robert Sinto, et al. "Coronavirus Disease 2019: Tinjauan Literatur Terkini." Jurnal Penyakit Dalam Indonesia (2020). 